\title{
Desigualdade e Corrupção no Republicanismo de Maquiavel $^{*}$
}

\author{
Ricardo Silva \\ Professor do Departamento de Sociologia e Ciência Política da Universidade Federal de Santa Catarina (UFSC). \\ Florianópolis, SC, Brasil. \\ E-mail: rsilva@cfh.ufsc.br. ORCID: https:/ / orcid.org/0000-0001-5447-4859
}

\section{INTRODUÇÃO}

E ntre os principais autores da longa tradição do pensamento político republicano, poucos refletiram tão proficuamente sobre as vicissitudes das repúblicas corrompidas quanto Nicolau Maquiavel. Este artigo pretende realizar um duplo objetivo: por um lado, contribuir para uma interpretação dos textos do teórico político florentino nos quais ele esboça sua visão sobre o papel da desigualdade no processo de corrupção das repúblicas; por outro, mostrar que os resultados desse esforço interpretativo contêm lições potencialmente úteis para o aprimoramento da teoria política do neorrepublicanismo.

Esse duplo objetivo é perseguido com base na hipótese de que os principais expoentes do neorrepublicanismo, quer em suas análises históricas da contribuição de Maquiavel, quer em suas reflexões sobre as repúblicas contemporâneas, tendem a subestimar o grau em que a dimensão socioeconômica da igualdade é constitutiva da liberdade política. Tal subestimação dá lugar a uma conceituação insuficiente do tipo de desigualdade geradora de um ambiente propício à corrupção das repúblicas. Embora corretamente atentos à dimensão jurídica da

\footnotetext{
* Versões preliminares do presente artigo foram apresentadas, ao longo de 2018, nos seguintes eventos: Seminários do DCP/USP, São Paulo, 3 de maio; Colóquio: A Tradição republicana e o legado de Roma, Florianópolis, 16 e 17 de maio; I Encontro de Teoria Política e Pensamento Político Brasileiro, Rio de Janeiro, 26 e 27 de junho; e na Área Temática de Teoria Política no $11^{\circ}$ Encontro da Associação Brasileira de Ciência Política, 31 de julho a 3 de agosto. Sou grato a organizadores, debatedores e audiências desses encontros, bem como ao Conselho Nacional de Desenvolvimento Científico e Tecnológico (CNPq), que apoia com bolsa de produtividade a pesquisa da qual se originou este artigo (processo n. 308471/2015-6).
}

DADOS, Rio de Janeiro, vol.63(3): e20190070, 2020.

https://doi.org/10.1590/dados.2020.63.3.216 
igualdade e à dimensão moral da corrupção, os neorrepublicanos padecem da falta de uma perspectiva sociológica para uma conceituação mais abrangente do fenômeno da desigualdade e, consequentemente, para um diagnóstico mais preciso da corrupção.

O artigo seguirá os seguintes passos: na próxima seção, após indicar as principais formulações de Maquiavel sobre a relação entre igualdade e liberdade e, inversamente, entre desigualdade e corrupção, apresento as interpretações de John Pocock e Quentin Skinner - dois dos mais influentes intérpretes neorrepublicanos de Maquiavel - a propósito do tema. Nas duas seções subsequentes, procuro evidenciar os limites dessas interpretações, investigando mais detidamente o que Maquiavel nos diz sobre o processo de corrupção das duas repúblicas que ele estudou em profundidade. Primeiro, veremos como ele enquadra a relação entre desigualdade e corrupção em sua investigação da antiga república romana, levada a cabo nos Discursos sobre a Primeira Década de Tito Lívio (daqui por diante apenas Discursos); depois, como o pensador trata do mesmo problema em sua cidade natal, especialmente em História de Florença. Tanto no caso de Roma como no de Florença, creio ser possível revelar mais detalhadamente a visão do florentino sobre a desigualdade econômica como uma espécie de "problema perene" para a preservação de uma república bem ordenada. Na conclusão, resumo o argumento e deixo a sugestão de que o enquadramento maquiaveliano da corrupção é potencialmente útil para o refinamento analítico do próprio conceito de liberdade republicana, na medida em que lança luz sobre formas mais insidiosas de dependência, formas que escapam à estrita identificação entre dependência e dominação, própria da teoria neorromana da liberdade (Pettit, 1997; Skinner, 2008; Maynor, 2003).

\section{MAQUIAVEL E O NEORREPUBLICANISMO SOBRE DESIGUALDADE E CORRUPÇÃO}

É curioso não haver qualquer ocorrência do termo desigualdade em $O$ Príncipe, uma vez que Maquiavel afirma, em outras de suas obras, que a existência ou introdução da desigualdade é condição indispensável à fundação dos principados (D.I.55, DFGF:66) ${ }^{1}$. O termo corrupção e seus derivados também são raramente empregados na obra mais famosa de Maquiavel; quando o são, denotam a corrosão da virtude marcial indispensável aos soldados (P.VII:127, P.XVII:197), embora, em uma única passagem, sejamos informados de que o fenômeno da corrupção é comum a "povos, soldados e grandes" (P.IX:213). 
Sendo a desigualdade a condição natural dos principados, não há porque supor qualquer relação entre desigualdade e corrupção nessa forma de governo. Como Maquiavel deixa claro nos Discursos, a corrupção dos principados, antes mesmo de deteriorar o espírito de combate de seus exércitos, deve-se à degeneração da virtù e à perda de espírito público dos príncipes, o que ocorre sempre que estes perdem de vista a segurança e o bem-estar da cidade e de seus súditos e passam a agir para exclusiva satisfação de seus interesses e dos apetites insaciáveis de suas cortes. Deixando de ser "prudente e justo", o príncipe corrompido aferra-se a um comportamento balizado pela desprezível crença de que tudo o que lhe cabe é "sobrepujar os outros em suntuosidade, lascívia e em todos os outros tipos de licença" (D.I.2:15).

Se a desigualdade é requisito indispensável a quem deseja fundar ou manter um principado, a igualdade é a base para a fundação e a manutenção das repúblicas, como se lê no enunciado que dá título ao capítulo 55 do primeiro livro dos Discursos: "onde existe igualdade não se pode criar um principado; e onde ela não existe, não se pode criar uma república" (D.I.55:158)2. E se a igualdade é indispensável às repúblicas, a desigualdade as leva à corrupção. No capítulo XVII do primeiro livro dos Discursos, Maquiavel formula o problema do modo mais claro e direto possível, ao afirmar que a "corrupção e pouca aptidão à vida livre provêm de uma desigualdade existente na cidade" (D.I.17:71). Como interpretar tal enunciado, tão decisivo para os objetivos do presente artigo? Tudo o que se pode afirmar, por enquanto, é que, nas repúblicas, que se distinguem por seu "modo de vida livre", a desigualdade é uma "causa" de corrupção ${ }^{3}$, ainda que se possa acrescentar, como o faz Cadoni (2017:220), que se trata de uma relação de reciprocidade: para Maquiavel, "da corrupção, a 'desigualdade' é ao mesmo tempo causa e consequência", sendo "que os dois conceitos são deveras conjugados para aparecerem separados". Mas em que consiste essa desigualdade causadora de corrupção? E o que Maquiavel tem em mente quando se refere à corrupção proveniente da desigualdade?

Um campo promissor para explorarmos respostas às questões acima encontra-se nos esforços de incorporação do pensamento político de Maquiavel na tradição republicana. Movimento intelectual com forte influência na historiografia das ideias e na teoria política normativa nas últimas quatro ou cinco décadas (Rodgers, 1992; Laborde e Maynor, 2008), o chamado republican revival tem situado Maquiavel no centro de uma tradição moderna que remonta ao pensamento político e cons- 
titucional na antiguidade, seja na antiguidade romana (Skinner, 2002), seja na ateniense (Pocock, 2003). Não obstante suas disputas internas, o neorrepublicanismo tem contribuído para revelar a genealogia e defender a contemporaneidade de uma tradição de pensamento político organizada em torno de uma visão de liberdade apresentada como alternativa à concepção liberal, postulando a indissociabilidade entre a liberdade individual e a liberdade política (Silva, 2015a).

Em The Machiavellian Moment, John Pocock mostra-se atento à conexão entre desigualdade e corrupção apontada por Maquiavel, mas reconhece a dificuldade para a definição da noção de desigualdade, uma vez que o pensador florentino não nos diz "o que é a 'igualdade' [...] de modo formal e expositivo". Daí que o intérprete deva preocupar-se em "coletar evidências do pensamento de Maquiavel sobre o assunto". Não passa despercebida ao historiador neozelandês a tensão entre duas explicações oferecidas por Maquiavel para a corrupção da república romana: “há uma análise sociológica bem como uma análise meramente moral da corrupção a ser encontrada nos Discorsi" (Pocock, 2003:208).

Por um lado, a corrupção é compreendida como uma "condição moral afetando os poderosos e seus dependentes com igual corrosividade; e suas origens nessa instância são puramente morais" (Pocock, 2003: 209). Em Roma, o comportamento faccioso dos líderes e seus seguidores originou-se, em última análise, do enfraquecimento da virtude marcial que se seguiu ao triunfo completo da cidade sobre seus inimigos. Na ausência do medo dos inimigos, os romanos passaram a eleger para os cargos públicos indivíduos cujo mérito resumia-se a agradar com favores os que os circundavam. Em seguida, o povo permitiu que se alçassem a tais cargos simplesmente os mais poderosos, o que gerou temor nos mais virtuosos e a consequente inibição de sua participação na disputa político-institucional.

Por outro lado, prossegue Pocock, Maquiavel concebe a corrupção como um fenômeno motivado por determinadas condições socio-econômicas. Isso estaria evidente na discussão sobre a incompatibilidade entre o ordenamento das repúblicas e a existência de um setor específico dos grandi, os gentis-homens (gentiluomini), empreendida no capítulo XLV do livro primeiro dos Discursos. Maquiavel define os gentis-homens como aqueles "que vivem ociosos das rendas de suas grandes posses, sem cuidado algum com o cultivo ou qualquer outro trabalho necessário à subsistência". Esses indivíduos "são perniciosos 
em todas as repúblicas", especialmente quando, por meio de suas "fortunas", "comandam em castelos e têm súditos que lhes obedecem" (D.I.55:161). Pocock observa que a malignidade dos gentis-homens, invectivados por Maquiavel, diz respeito ao fato de eles constituírem facções e milícias próprias, fenômenos típicos de repúblicas corrompidas. Ora,

se são os castelos e as fortunas dos gentiluomini que os transformam em causa de desigualdade e corrupção, a república incorrupta deve ser um estado de ausência de dependências militares e uma característica da "igualdade" deve ser a de que todos são igualmente guerreiros. (Pocock, 2003:210).

Uma ética do cidadão-soldado não pode florescer quando os que lutam na guerra dependem dos recursos daqueles que os comandam para sua própria subsistência. Portanto, "a independência econômica do guerreiro e do cidadão são pré-requisitos contra a corrupção" (Pocock, 2003:210).

É compreensível que Pocock tenha detectado esse duplo registro (moral e sociológico) no tratamento dispensado por Maquiavel ao tema da corrupção. Mas é duvidoso que essa duplicidade deva ser tratada como uma ambiguidade, como se estivéssemos diante de princípios explicativos heterogêneos. Ainda mais questionável é sua tentativa de superar a presumida ambiguidade apelando à figura do "cidadão-soldado", tipo que o historiador apresenta como o portador da virtude cívica no republicanismo do pensador florentino. Para Pocock, a ética do cidadão-soldado é uma herança aristotélica do "momento maquiaveliano", a chave para compreender a relação entre o interesse particular do cidadão ordinário e o bem comum, cuja persecução confunde-se com a defesa militar da pátria. Mas não está claro - na verdade é bastante contestável, como assinalam críticos de Pocock das mais diversas tendências (Sullivan, 1992; Nadon, 1996; Vatter, 2000; McCormick, 2003; Sparling, 2017) - que Maquiavel sustentasse essa visão heroica da virtude cívica, ou que tomasse a indisposição do cidadão ao sacrifício na guerra como a causa da corrupção das repúblicas. Exatamente o contrário disso pode acontecer, como revela a avaliação positiva do florentino dos episódios de secessão (secessio) e recusa ao alistamento militar (detractio militae) protagonizados pela plebe romana (Pedullà, 2018). 
O que se depreende da leitura de Pocock sobre a relação entre desigualdade e corrupção em Maquiavel pode ser resumido na sugestão de que as imensas somas de riquezas e renda concentradas em mãos privadas corroem a virtude cívica e ameaçam a liberdade apenas quando os "gentis-homens" mobilizam tais fortunas para tornarem-se espécies de potentados armados, condição intolerável a qualquer república. Sob o comando deste segmento específico dos grandi, o cidadão-soldado degrada-se num tipo que luta por motivações estritamente facciosas e lesivas ao bem comum. Como esclarece o próprio Maquiavel, esse segmento específico da categoria dos "gentis-homens", composto por aqueles que "comandam em castelos e têm súditos que lhes obedecem", são os inimigos mortais das repúblicas, a ponto de ele apresentar como "conclusão" de sua discussão sobre o assunto a fria constatação de que "quem quiser criar uma república onde houver muitos gentis-homens não poderá fazê-lo sem antes os eliminar todos" (D.I.55: 162). Contudo, não se deve perder de vista que esse seguimento mais ofensivo dos gentis-homens, que bem se adequa à nobreza feudal (McKenzie, 1982:213; Kocis, 1998:177), não representa o conjunto dessa fração dos grandi. Embora os extremamente ricos e armados sejam os "mais perniciosos" à igualdade necessária às repúblicas, não deixam de ser "perniciosos em todas as repúblicas" aqueles que simplesmente desfrutam de suas "grandes posses", inteiramente alheios ao "cuidado [...] com o cultivo" ou a qualquer tipo de "trabalho necessário à subsistência" (D.I.55:161). Maquiavel não nos informa se há qualquer obstáculo para que o "pernicioso" se converta no "mais pernicioso".

A análise de Pocock sofre os efeitos de sua exagerada ênfase no tipo do cidadão-soldado como a encarnação possível da virtude cívica do cidadão comum. Ao associar os efeitos corruptores da desigualdade material exclusivamente à presença ameaçadora dos muito ricos e armados, ele perde de vista os efeitos deletérios da existência dos simplesmente muito ricos, dos rentistas improdutivos que, embora militarmente desarmados, possuem outros meios para comprometer, por vias mais sutis e insidiosas, a liberdade das repúblicas. Daí a equivocada afirmação de Pocock de que o termo "desigualdade" (que ele usa entre aspas), "não conota nem desigualdade de riqueza, nem desigualdade de autoridade política", e que "não há qualquer razão para supor que Maquiavel objetava uma ou outra" (Pocock, 2003:209)4. 
Essa elisão da dimensão socioeconômica tanto da igualdade necessária às repúblicas como da desigualdade que as leva à ruína reflete-se em um entendimento da corrupção que enfatiza as dimensões moral e jurídica do conceito. Isso pode ser bem observado na contribuição de Quentin Skinner. Embora procure distanciar-se de muitos dos aspectos controversos da interpretação pocockiana do republicanismo de Maquiavel, em especial da tese da gênese aristotélica do republicanismo renascentista (Silva, 2010), Skinner acompanha seu colega da "Escola de Cambridge" na superestimação do grau de acomodação do pensamento do secretário florentino à tradição do humanismo cívico italiano. Já em sua primeira incursão nos textos do florentino, realizada em As fundações do pensamento político moderno, Skinner o apresenta como um fiel seguidor da idade de ouro do humanismo cívico. Examinando o texto dos Discursos contra o pano de fundo da herança de humanistas do quattrocento florentino, exemplarmente representados por Leonardo Bruni, Skinner sustenta que Maquiavel tinha um "compromisso fundamental" com o "mesmo conjunto de valores" de seus predecessores, e que ele "endossa inteiramente" a visão humanista de que a preservação da liberdade depende do compromisso ativo e virtuoso do conjunto da cidadania com o bem comum (Skinner, 1996:176).

Em um estudo subsequente sobre "o ideal republicano de liberdade", Skinner detalha sua visão sobre conceito de corrupção no republicanismo renascentista, argumentando que "corrupção é um termo que os teóricos republicanos usam para denotar nossa tendência natural de ignorar as demandas de nossa comunidade tão logo elas entrem em conflito com a persecução de nossa vantagem imediata" (Skinner, 1990: 304). A maximização da liberdade individual numa sociedade política requer que os indivíduos ajam "primordialmente como cidadãos virtuosos, situando o bem comum acima da persecução de qualquer fim individual ou faccional". A conclusão é que, para pensadores republicanos como Maquiavel, "corrupção é, em suma, simplesmente uma falha de racionalidade, uma incapacidade de reconhecer que nossa própria liberdade depende de nosso compromisso com uma vida de virtude e serviço público" (Skinner, 1990:304).

Quando Skinner se volta ao estudo das causas da corrupção no pensamento político do Renascimento tardio, ele reconhece que autores da geração de Maquiavel e Guicciardini distanciam-se dos humanistas de gerações anteriores. Enquanto estes ignoravam ou elogiavam o papel da riqueza material na vida republicana, aqueles deixaram-se tomar 
pela preocupação de que o crescimento da riqueza privada em uma república favorece um ambiente propício à corrupção. Mas Skinner não aprofunda o exame dessa constatação, tampouco oferece qualquer explicação dos mecanismos que fazem do crescimento da riqueza privada uma fonte de corrupção. Na ausência de uma investigação mais aprofundada sobre esse tema, ele é levado a concluir que Maquiavel fornece "uma contribuição relativamente ortodoxa a uma tradição já estabelecida de pensamento político republicano" (Skinner, 1996:201). Assim, a corrupção decorreria de uma espécie de miopia moral dos cidadãos. Movidos por interesses privados imediatos e mostrando-se incompetentes para o reconhecimento do papel instrumental do serviço público na manutenção da liberdade individual, eles se entregam a práticas em que o espírito público dá lugar ao espírito faccioso.

Ao definir a corrupção como uma simples "falha de racionalidade" dos indivíduos, o intérprete torna dispensável a investigação sobre o significado da desigualdade que Maquiavel vê como causadora da corrupção. Não se trata de negar que a observação do comportamento individual forneça um rico e indispensável estoque de evidências dos sintomas da corrupção. Os textos de Maquiavel estão repletos de exemplos de indivíduos cujas intenções e ações configuram padrões éticos incompatíveis com preservação do bem comum. O problema está em fixar a visão nos discursos e comportamentos corrompidos sem uma correspondente atenção às condições socioeconômicas e institucionais que constituem o ambiente favorável para a proliferação de tais comportamentos. Tem razão uma crítica recente quando afirma que "para Skinner, a razão e as ideias são os fundamentos da virtude", e devido à leitura de Maquiavel por meio de um "enquadramento humanista", ele "negligencia os momentos em que o florentino está claramente preocupado com a compreensão das origens socioeconômicas da corrupção" (Maher, 2016:1008). Uma visão mais compreensiva da relação entre desigualdade e corrupção nas repúblicas requer que voltemos aos textos de Maquiavel.

\section{AS LEIS AGRÁRIAS E A CORRUPÇÃO EM ROMA}

No capítulo 37 do primeiro livro dos Discursos, Maquiavel faz alusão a fatos ocorridos no período compreendido entre a eleição de Tibério Graco para o tribunato da plebe, em 134 a.C. e a tomada do poder por Júlio Cesar, em 49 a.C. Trata-se do último século da república romana, o século de um processo de corrupção que culminou com o colapso da 
república e com a instauração da tirania cesarista. O foco da análise de Maquiavel são as reformas redistributivas iniciadas por Tibério Graco e, uma década depois, retomadas por Caio, seu irmão e seguidor ${ }^{5}$.

A visão de Maquiavel sobre os conflitos sociais e a marcha da corrupção em Roma divide-se claramente em duas fases: antes e depois das iniciativas dos irmãos Graco para reformar e tornar efetivas as leis agrárias de Roma. Se antes da explosão do conflito redistributivo protagonizado pelos tribunos da plebe, as animosidades entre o povo e a nobreza acabavam encontrando desaguadouros institucionais que permitiam a manutenção da liberdade pela resolução política dos conflitos sociais, depois dos Gracos as animosidades levariam Roma "ao conflito armado e ao derramamento de sangue, fugindo a qualquer modo e costume civil" (D.I.37:115).

A história da questão da propriedade agrária em Roma não chega a ser discutida por Maquiavel, embora ela seja um pressuposto da narrativa e o pano de fundo contra o qual se desenrolam as iniciativas dos irmãos Graco. Com o passar dos séculos, a cidade vê sua estrutura fundiária alterar-se do modelo fundacional organizado em torno de um misto entre pequena propriedade (heredium), terras comunais (ager gentilicus) e terras públicas (ager publicus) para um sistema dominado pelo latifúndio (Roselaar, 2010). Um dos mecanismos que contribuiu para essa transformação foi a natureza militar e expansionista de Roma. Com a expansão imperial da cidade e a consequente intensificação de sua atividade militar, os soldados romanos passaram a permanecer em campanha por períodos de tempo cada vez mais longos, e em lugares cada vez mais distantes de suas pequenas propriedades rurais. Isso resultava na crescente impossibilidade do adequado cultivo de suas terras, deixadas aos insuficientes cuidados familiares. Os militares pertencentes ao patriciado não sofriam as mesmas consequências, pois estes dispunham de muitos meios e recursos, especialmente a posse de escravos, para manter suas terras produtivas. Premidos por dívidas e pela inviabilidade econômica de suas terras, os pequenos proprietários passaram a vender seu patrimônio aos proprietários mais abastados, acelerando o processo de concentração fundiária.

Antes dos Gracos, inúmeras tentativas de enfrentamento da questão foram realizadas de modo a conter a crescente desigualdade entre patrícios e plebeus. A mais importante foi a lei Licínia, promulgada em 367 a.C., limitando a posse de terras públicas (ager publicus) a 320 acres por 
indivíduo. No entanto, essas e outras iniciativas, sempre combatidas pelos patrícios por meio de vários artifícios, provaram-se impotentes para reverter o avanço da desigualdade. As manobras protelatórias do senado, a indiferença constante e impune à lei e a contínua compra das terras de plebeus endividados estavam entre os expedientes que perpetuavam a dinâmica da concentração fundiária. Com frequência, o senado conseguia corromper ao menos um tribuno para exercer seu poder de veto contra as reformas propostas por seus pares.

Invariavelmente, os contextos de discussão e aprovação das leis agrárias caracterizavam-se pela exaltação dos ânimos dos diferentes setores. De acordo com Maquiavel, "nunca se falou de tal lei em Roma sem que houvesse confusão na cidade" (D.I.37:113). Quando os irmãos Graco retomam a bandeira da lei agrária, um novo ciclo de conflitos se inicia. Imediatamente após sua eleição para o tribunato da plebe, Tibério Graco deu início à luta pela aprovação da lei Semprônia, que, no essencial, era uma repetição da lei Licínia, transformada em letra morta desde sua promulgação (Roselaar, 2010:230). Tibério estava determinado a fazer cumprir os estritos limites de 500 jeiras (320 acres) para a posse individual de terras públicas, o que contrariava intensamente os grandes proprietários. Os conflitos que se seguiram à iniciativa envolveram incontáveis manobras, tanto da parte do senado quanto do lado de Tibério e seus seguidores, quer para o bloqueio, quer para a passagem da lei. Ações completamente estranhas aos modos ordinários de resolução das disputas deram o tom dos acontecimentos.

Confrontado com a absoluta inviabilidade de aprovação da lei no Senado, Tibério resolve submetê-la a uma assembleia popular, o concilium plebis, num gesto que, embora não explicitamente ilegal, significava uma afronta ao brio dos senadores. Estes, por sua vez, precavendo-se das intenções de Tibério, decidiram cooptar um dos tribunos para exercer seu poder de veto contra Tibério na assembleia popular. Porém, em mais uma manobra ousada, Tibério expulsa Octávio, o tribuno cooptado pelo Senado, da assembleia dos plebeus. Embora a manobra tenha sido levada a cabo por meio do voto da plebe, ela resultou em graves acusações a Tibério. A remoção física de Octávio da assembleia soava como uma violação de sua sacrossantidade, uma das mais caras garantias de que dispunham os tribunos da plebe para o cumprimento intimorato de suas funções. Tibério acabou neutralizando os expedientes do Senado para bloquear a passagem da lei, mas esse êxito provisório custou-lhe a própria vida. Desguarnecido ante 
ao Senado e ao patriciado desejoso de vingança, o tribuno é assassinado no fórum romano. Uma década depois da morte de Tibério, Caio retoma as políticas do irmão, e em meio a conflitos violentos, vendo-se impotente para evitar a reversão das reformas aprovadas por Tibério e reforçadas por ele próprio, o tribuno comete o suicídio.

Examinando os acontecimentos que sobrevieram ao trágico desfecho das iniciativas dos Gracos, Maquiavel registra que Roma jamais voltou a ter no conflito a causa da liberdade. As animosidades entre as classes prosseguiram de modo cada vez mais incivil. Na medida em que os magistrados perdiam legitimidade, tanto a plebe como o patriciado assumiam comportamentos facciosos, recorrendo a "remédios privados", sendo que "cada uma das partes tratou de constituir um cabeça que a defendesse". Veio então "o tempo das guerras civis". Primeiro observou-se a luta entre Sila, pelo lado da nobreza, e Mário, apoiado pela plebe, com a vitória do primeiro e a consequente diminuição dos poderes da plebe. Depois, os partidos desses dois comandantes foram herdados por Pompeu e César. Eclodida a luta entre ambos, César, herdeiro do partido de Mário, sobrepujou Pompeu, e foi com essa vitória que Roma conheceu seu "primeiro tirano; de tal modo que nunca mais a cidade foi livre" (D.I.37:115).

Maquiavel é o primeiro a constatar a aparente contradição entre sua narrativa do resultado dos conflitos em torno da lei agrária e sua afirmação anterior de que "as inimizades, em Roma, entre o Senado e a plebe mantiveram a cidade livre, visto que delas nasciam leis favoráveis à liberdade". Antecipando-se à provável dúvida de seus leitores, o autor questiona se não estaria "em desacordo com tal conclusão o resultado dessa lei agrária"? Maquiavel não ignora a dificuldade do problema, mas afirma que "nem por isso renuncio a tal opinião" (D.I.37:116). Ou seja, independentemente de reconhecer que a reedição das leis agrárias pelos Gracos "arruinou inteiramente a liberdade romana" (D.I.37:115), ele continua sustentando a opinião de que o conflito social foi a "causa primeira" da liberdade na cidade. $\mathrm{O}$ fato decisivo é que, nas circunstâncias em que os Gracos retomam a plataforma da lei agrária, Roma já havia atingido um nível de desigualdade material entre a nobreza e a plebe de reversão altamente improvável por meios ordinários. O enriquecimento desmesurado da nobreza em detrimento da plebe representava o verdadeiro fator de desordem na república romana, uma vez que "as repúblicas bem-ordenadas devem 
manter rico o público e pobres seus cidadãos" (D.I.37:113)6. As políticas dos irmãos Graco nada mais foram do que tentativas ineficazes de corrigir essa crescente desigualdade material.

Embora Maquiavel censure a falta de "prudência" dos Gracos, ele lhes louva a "intenção" (D.I.37:116). O elogio à intenção pode ser visto como uma demonstração inequívoca da simpatia do florentino pelo programa distributivista dos tribunos. Já a alegada falta de prudência dos líderes da plebe é tema mais controverso. Há duas interpretações plausíveis. A primeira - e a mais ancorada em evidências textuais sugere que a imprudência dos tribunos consistiu em cometer o erro de "tentar eliminar a desordem que cresceu numa república, criando para isso uma lei voltada demais para o passado" (D.I.37:116). Com isso, eles acabaram por "acelerar o mal" gerado pela "desordem" que pretendiam combater. Defrontados com a inviabilidade de seu programa, devido à obstinada reação do patriciado, tudo o que deveriam ter feito era renunciar às próprias intenções e ganhar tempo, pois "em se temporizando, o mal demora mais a chegar" (D.I.37:116)7. Não passa despercebido por alguns intérpretes de Maquiavel o caráter excepcional desse aconselhamento retrospectivo à inação dos Gracos. Conforme a observação de um desses intérpretes, "o conselho contradiz diretamente inúmeras outras observações de Maquiavel em que ele privilegia a atividade à passividade, e elogia a audácia e a capacidade de decisão como elementos cruciais da virtù" (Fontana, 2017:244).

A segunda interpretação sobre o que Maquiavel considerava a imprudência dos Gracos é diametralmente oposta à primeira. Ao invés de inação, o florentino estaria aconselhando, ainda que veladamente, uma ação mais incisiva. Para considerar essa hipótese interpretativa, é necessário redobrar a atenção à natureza retórica do texto de Maquiavel $^{8}$. Como observa Eunice Ostrensky, o texto do capítulo 37, utilizando a técnica humanista de argumentação in utramque partem, ou seja, apresentando os dois lados de uma questão, dá voz a duas versões diferentes sobre o papel dos Gracos. A primeira é a versão convencional, desposada pelas autoridades do pensamento político romano, segundo a qual, em última análise, os Gracos agiram movidos pelo desejo de tornarem-se príncipes em Roma, numa ameaça explícita à ordem republicana. A segunda é a versão do próprio Maquiavel, quem, assumindo a figura do "orador habilidoso", procura "convencer uma plateia a abandonar suas opiniões iniciais e adotar as que ele próprio apresenta" (Ostrensky, 2019:58). 
Deve-se também levar em conta a natureza da própria audiência imediata do texto. Dedicados a Cosimo Rucellai e Zanobi Buondelmonti, jovens de famílias ricas e influentes de Florença, além de amigos e patrocinadores de Maquiavel nos encontros nos Orti Oricellari, os Discursos visavam a demover a elite republicana florentina de suas crenças mais refratárias à participação do povo, especialmente do popolo minuto, na estrutura de poder da cidade (McCormick, 2006). Por isso os esforços de persuasão do autor não poderiam dispensar a incorporação, em alguma medida, da opinião fortemente negativa que sua audiência nutria sobre as políticas dos irmãos Graco, uma herança transmitida pelo humanismo do quattrocento (Nelson, 2004:70). No entanto, encapsulada em tal invólucro retórico estaria não apenas uma demonstração explícita de simpatia com a causa dos tribunos, mas também a sugestão mais subliminar de que o grande erro dos Gracos foi o de não se guarnecerem com os meios necessários para dar a resposta adequada à violenta (e previsível) reação da nobreza a seus intentos redistributivistas.

Essa interpretação parece sintonizada com o que Maquiavel escreve, no capítulo IX de O Príncipe, a propósito dos Gracos como prospectos malogrados de príncipes civis. A ruína desses tribunos, argumenta, adveio de ambos ignorarem o modo correto de obtenção do apoio popular, ignorância evidenciada em sua indisposição para um curso de ação mais impetuoso. Fracassaram os Gracos como sempre fracassará o líder popular que, não demonstrando "coragem" e não podendo "comandar", "se convence de que o povo o libertará quando for oprimido pelos inimigos ou pelos magistrados" (P.IX:151). De acordo com um dos principais proponentes dessa linha interpretativa, Maquiavel sugere que o eventual êxito das reformas dos Gracos dependeria basicamente da disposição dos tribunos para "eliminarem o mais intransigente obstáculo a seus desígnios, ou seja, o Senado romano" (McCormick, 2009:304).

Diante dessas duas interpretações conflitantes sobre o significado atribuído por Maquiavel à imprudência dos Gracos, permanecerá a dúvida se a crítica do florentino tinha em vista qualquer iniciativa de ação dos tribunos destinada à redistribuição de terras, o que justificaria o conselho à inação, ou se visava apenas à escolha feita pelos Gracos, com a decisão de enfrentarem desarmados a reação previsivelmente violenta do patriciado romano. Afortunadamente, para os fins da discussão realizada no presente artigo, não precisamos endossar uma ou outra 
dessas interpretações. Embora a questão seja relevante para historiadores das ideias dedicados a compreender os remédios vislumbrados por Maquiavel para as repúblicas corrompidas, o que aqui se busca é compreender o diagnóstico do autor sobre as causas da corrupção das repúblicas. É no campo do diagnóstico, não no da terapêutica, que as lições do florentino se mantêm atuais e com grande potencial de contribuição para a teoria política contemporânea.

Independentemente da natureza dos remédios que Maquiavel idealizava oferecer aos reformadores republicanos que enfrentassem dilemas semelhantes ao dos Gracos, o fato é que seu diagnóstico do processo de corrupção da república romana não pode ser compreendido sem que se considere o papel central atribuído à desigualdade material no rol de causas da decadência. Em situações caracterizadas por desmesurada desigualdade de riqueza entre os cidadãos, o conflito fundamental entre os grandes e o povo perde a propriedade de gerar efeitos benéficos à manutenção da liberdade, degradando-se em combates facciosos e inteiramente alheios ao bem comum. Maquiavel constata a relativa aquiescência dos grandes com o desejo da plebe de conquistar reconhecimento público na forma de novas magistraturas. Em suas palavras, a "nobreza romana sempre cedeu à plebe sem excessivos tumultos quando o assunto eram honras". No entanto, "os homens estimam mais o patrimônio do que as honras", e quando as demandas da plebe passaram a visar não apenas reconhecimento, mas também redistribuição, a classe senatorial reagiu com "grande obstinação", obrigando a plebe a recorrer, através de seus tribunos, a "meios extraordinários" para "saciar seu apetite" (D.I.37:116).

A despeito das consequências catastróficas ocasionadas pela mudança do objeto das disputas - agora também a redistribuição de riqueza e não apenas o acesso a honras e cargos públicos (Silva, 2013) -, Maquiavel mantém sua avaliação positiva do conflito social na história de Roma, tal como apresentada nos Discursos I.4. O fato, porém, é que a corrupção, mesmo a da mais perfeita forma de governo, é sempre, em última análise, uma questão de tempo. A inevitabilidade da corrupção e da queda é o destino a ser enfrentado por todos os corpos sublunares. O naturalismo de Maquiavel não deixa espaço para a postulação de formas políticas imperturbavelmente estáveis ${ }^{9}$. Os movimentos alternados de subida e queda, até a chegada do fim, modulam o desenvolvimento dos corpos naturais e políticos. Ou seja, "como todas as coisas do mundo estão em movimento e não podem ficar paradas, é preciso 
que estejam subindo ou descendo" (D.I.6:32). Embora as modulações desse movimento sejam sensíveis à ação humana, elas resultam em grande medida de acidentes protagonizados pela fortuna. A contingência, a transitoriedade e a finitude são caraterísticas indissociáveis dos eventos e processos históricos na visão de Maquiavel (Vatter, 2000). Conforme o enunciado de abertura do livro terceiro, "a grande verdade é que todas as coisas do mundo têm seu tempo de vida" (D.III.1:305). Contudo, se corrupção é inevitável, ela pode vir mais cedo ou mais tarde conforme a menor ou maior qualidade de leis e ordenações e conforme o grau de virtù com que os homens conduzem suas ações quando confrontados com os efeitos corrosivos do tempo e com os ímpetos desestabilizadores da fortuna.

Seja como for, as palavras conclusivas da análise de Maquiavel sobre o conflito redistributivo associado às leis agrárias apresentam este conflito como fator de preservação da república, contribuindo, ao longo do tempo, mais para a manutenção do que para a supressão da liberdade. Em suas palavras,

embora o conflito da lei agrária tenha demorado trezentos anos para acarretar a servidão de Roma, isso teria ocorrido muito mais cedo caso a plebe, seja com essa lei, seja com outros desejos seus, não tivesse refreado a ambição dos nobres (D.I.37:116).

\section{DESIGUALDADE, PATRONAGEM E CORRUPÇÃO EM FLORENÇA}

A discussão realizada na seção anterior procurou sustentar que a desigualdade socioeconômica representa um fator decisivo na visão de Maquiavel sobre as causas da corrupção da república romana, a despeito da reduzida atenção que o tema tem recebido entre os neorrepublicanos. Como se pode depreender da análise maquiaveliana da lei agrária, o aprofundamento da desigualdade no sistema de propriedade fundiária de Roma gerou um ambiente propício para a irrupção da dinâmica facciosa e violenta do último século de vigência da república.

Mas se a análise contida nos Discursos é clara ao estabelecer a relação de causalidade entre desigualdade e corrupção, ela é elusiva quanto aos mecanismos mediante os quais essa relação se estabelece. Exceto no caso extremo dos gentis-homens armados, pouco é dito sobre as formas concretas das instituições e práticas que convertem desigual- 
dade em corrupção. Para sanar essa limitação, é necessário refletir sobre o que escreve o florentino acerca do fenômeno da corrupção em outra "república" - se assim pode-se denominar o regime que atravessou séculos na cidade natal de nosso autor ${ }^{10}$. Entre todos os textos de Maquiavel, História de Florença é, de longe, a fonte mais rica para tal reflexão. Como observa Newton Bignotto, essa obra pode ser lida "como um grande tratado sobre a corrupção", pois o retrato que emerge da narrativa revela "uma cidade corrompida, dominada pelas lutas internas, e não a pátria de um humanismo triunfante" (Bignotto, 1991:187 e 191). Mas a interpretação da visão de Maquiavel sobre a relação entre desigualdade e corrupção em História de Florença requer tanto ou mais cuidados com a dimensão retórica do texto do que os necessários para a leitura dos Discursos, tanto pelo conteúdo da narrativa, como pela situação existencial do próprio autor. Vejamos.

Depois de quase uma década tentando reconciliar-se com a poderosa família Medici, objetivando retomar seu posto no serviço público, Maquiavel é finalmente convidado pelo cardeal Giulio de Medici para escrever a história da cidade. Em novembro de 1520, Giulio aceita os termos de uma minuta de contrato redigida pelo próprio Maquiavel, concedendo ao reabilitado servidor um salário correspondente a metade do que recebia em seus tempos na chancelaria (Black, 2013:242). Não deixava de ser um bom contrato a quem, em 1512, testemunhou o retorno dos Medici a Florença como uma sentença de morte da república a que servira por uma década e meia, ainda mais se lembrarmos que, antes de ser destituído de suas funções, Maquiavel enfrentou a acusação de conspirar contra o regime recém-instituído pelos Medici, tendo sido preso e torturado em fevereiro de $1513^{11}$.

Não é possível minimizar a força dos constrangimentos a que se submeteu Maquiavel na redação de uma história na qual os personagens principais eram os Medici. Para se ter uma ideia da delicadeza da tarefa a ser enfrentada, o cardeal Giulio, que encomendara a obra em 1520, tornou-se o papa Clemente VII, a quem Maquiavel dedicou a obra em 1525. John Najemy ressalta a natureza das dificuldades que influenciaram a narrativa da História de Florença. Entre as questões relevantes para o entendimento da obra, "uma das mais cruciais - talvez a questão central - é o tratamento dado por Maquiavel aos Medici em uma obra encomendada pelos Medici e a eles dedicada". E "o dilema e o drama" da decisão de Maquiavel de escrever uma história de Florença 
na qual "a totalidade do fenômeno dos Medici seria inevitavelmente um tema de primeira importância vai muito além dos fatos relativos ao contrato à dedicatória" (1982:552).

Maquiavel sabia que a riqueza e o poder dos Medici serviam mais como meios para corromper do que para regenerar a já tradicionalmente disfuncional república florentina. Como observa Raimondi (2018:161), "era impossível ignorar a presença dos Medici em Florença depois de seu retorno em 1512". Assim, "a questão enfrentada por Maquiavel era como restabelecer na cidade a república a despeito do poder empregado pelos Medici contra isso". Para o autor de História de Florença, "entender-se com os Medici significava convencê-los de que qualquer principado seria incapaz de sobreviver sem transformar-se numa república". Por isso, tanto quanto os Discursos - talvez até mais - História de Florença está longe de ser uma obra sistemática e voltada à formulação de enunciados isentos de ambiguidade. Também aqui é pouco instrutivo tomar o texto ao pé da letra, passando ao largo do imenso esforço retórico que marcou, desde o início, o desafio enfrentado pelo ex-secretário da república de Soderini: como expressar sua visão nada laudatória do papel das elites florentinas e, ao mesmo tempo, entregar uma obra palatável ou, ao menos, aceitável aos Medici? (Zuckert, 2017:381).

Na visão de Maquiavel, uma das características distintivas de Florença residia em sua propensão à proliferação de facções. Como afirma ainda no proêmio, "a maioria das outras repúblicas de que se tem notícia contentou-se com uma divisão", a exemplo de Roma, Atenas e "todas as outras repúblicas que floresceram naqueles tempos", nas quais a desunião entre os nobres e a plebe organizava a dinâmica político-institucional. Florença, porém, "não contente com uma, criou muitas" divisões: "primeiro os nobres se dividiram entre si, e depois houve a divisão entre os nobres e o povo, e, por último, entre o povo e a plebe". Maquiavel denuncia a natureza facciosa, corruptora e violenta dessas divisões, "origem de tantas mortes, tantos exílios, tantas destruições de famílias, como nunca ocorreu em nenhuma cidade de que se tenha memória" (HF.Proêmio:8). Diversamente de Roma, Florença raramente atravessou momentos em que as discórdias resultaram em boa ordem. Constituídas as inimizades entre nobres, muitas vezes fomentadas por acontecimentos fortuitos e de origem privada, não tardou para que 
as famílias em litígio se alinhassem em disputas mais amplas, como a que opunha os partidários do papa aos partidários do imperador, os guelfos e os gibelinos, respectivamente.

Mas um momento excepcionalmente feliz da história de Florença ocorre quando o povo, fortalecido pela consolidação das guildas, dá suporte às reformas de Giano della Bella, cidadão "de alta estirpe, mas amante da liberdade da cidade" (HF.II.13:96). Entre outras medidas, della Bella livrou a Senhoria do domínio dos nobres, fortaleceu o poder do gonfaloneiro e instituiu um critério de "fama pública" para julgamento dos cidadãos acusados de crimes. Maquiavel afirma que com tais "ordenamentos da justiça", como ficaram conhecidas as novas leis, "o povo granjeou muita reputação" (HF.II.13: 96). Chegava ao fim o regime dos "magnatas", selando o destino das famílias de antigas linhagens, cujo poder assemelhava-se ao dos gentis-homens da ordem feudal. Uma nova classe, nutrida no comércio e nas finanças, assumiria a hegemonia na política florentina. Por algum tempo, a partir do final do século XIII, Florença pôde viver livre do conflito faccioso entre os grandes, substituindo-o pelo conflito "natural" e regulado institucionalmente entre os nobres e o povo. Referindo-se a esse período, Maquiavel afirma que "nunca o estado de nossa cidade foi melhor e mais feliz do que naqueles tempos, visto que os homens estavam cheios de riqueza e reputação" (HF.II.15:100). E embora admitisse que, em várias circunstâncias, as forças em conflito tenham quase chegado ao combate armado, havia sempre um homem moderado em ambas as partes para persuadir seus pares a manterem as disputas no plano dos "debates"12.

No capítulo de abertura do terceiro livro, o autor expressa um sentimento ambivalente sobre o efeito da ruína das antigas linhagens no estatuto da igualdade em Florença. Por um lado, como ele registra ainda no livro primeiro, a exclusão dos magnatas da vida pública deixava Florença "nas mãos de homens formados no comércio" (HF.I.39: 73). Isso significava que a cidade não podia mais contar com a "virtù das armas e a generosidade de ânimo" de suas elites, iniciando um longo período de dependência de capitães mercenários para defesa militar. Por outro lado, a ruína da ordem dos magnatas, com suas armas privadas e conexões com o imperador e o papa, significava que Florença fora "reduzida" de um estado de "desigualdade" a um estado de "admirável igualdade" (HF.III.1:158). Se, por um lado, a 
cidade tornou-se "humilde e abjeta", por outro, ela passou a reunir as condições para que um "legislador sábio" pudesse "reordená-la em qualquer forma de governo" (HF.III.1:159).

A cidade, pela primeira vez, experimentava uma vitória sobre a ingovernável nobreza, enquanto o poder do popolo atingia seu ápice. Como assinala Najemy, aos poucos "a ação política da elite entrava no espaço cívico criado pelo povo" (2006:147). Segundo o próprio Maquiavel, os florentinos, "com a ruína dos Grandes, tinham alcançado tanta igualdade que os magistrados eram muito reverenciados - ao contrário do que ocorria antes". Por isso, "todos desejavam valer-se das vias ordinárias, sem violência privada" (HF, III.2: 160). Entretanto, como observa corretamente Amanda Maher (2020:519),

mesmo nesse momento de crescente fortalecimento do poder popular, a descrição de Maquiavel de uma cidade dividida em facções dirige nossa atenção para maneira pela qual os modos privados de poder explorados pela nobreza continuavam a debilitar as tentativas do povo de assegurar a ordem por meio de instituições e leis.

O fato é que, não obstante esse grande passo na estabilização da república, persistiam as causas básicas da corrupção. É preciso ter em conta que a exclusão dos magnatas não significou o fim da desigualdade socioeconômica, nem de suas consequências políticas e institucionais. A "admirável igualdade" a que se refere Maquiavel não se aplicava a esse domínio. Rigorosamente, havia pouco, exceto o título, a distinguir um magnata da antiga ordem de um "nobre popular" enriquecido no comércio. Muitas famílias que escaparam ao status de magnatas incluindo os Albizzi, os Ricci, os Medici, os Alberti e os Strozzi - eram tão ricas e socialmente conectadas quanto as famílias dos nobres exilados. Assim, "o único sentido em que as famílias dos não magnatas eram popolani era que eles não eram magnatas e podiam ocupar cargos públicos" (Najemy, 2006:38). Essas novas famílias litigantes, como os Albizzi e os Ricci, traziam à cena um novo tipo de conflito, no qual os cidadãos da elite usavam a influência conquistada sobre seus clientes e partidários para exercer seu domínio por meio da lei e da estrutura institucional originária das guildas.

No capítulo 5 do livro primeiro, Maquiavel dá a palavra a um orador anônimo, que se dirige à Senhoria como porta-voz de um conjunto de cidadãos "movidos pelo amor à pátria" (HF.III.5:164). O motivo 
imediato do discurso era a preocupação com a escalada do conflito faccioso entre os Albizzi e os Ricci, mas a mensagem tem um alcance mais amplo, funcionando como uma síntese do diagnóstico da corrupção decorrente do facciosismo da elite florentina. Inúmeros temas tipicamente maquiavelianos estão presentes na fala do patriota anônimo ${ }^{13}$. A "ambição pessoal", não a "utilidade pública", seriam os móveis da ação das famílias mais reputadas na cidade. A ambição gera as facções, cujos combates definem vencedores e perdedores, sendo que "as leis, os estatutos e as ordenações civis, não são ordenados de acordo com a vida livre, mas de acordo com a ambição do partido que se tornou vencedor" (HF.III.5:166). Esse personagem de Maquiavel, embora cônscio do elevado estágio de corrupção em Florença, alimentava expectativas de reformas saneadoras, instando a Senhoria a tomar iniciativa no controle das facções. Dizia que a "maldade da fortuna pode ser vencida com a prudência, pondo-se freio à ambição desses homens". E como isto poderia ser feito? Resposta: "anulando-se as ordenações que alimentam as faç̧ões e prendendo aqueles que não estão em conformidade com a verdadeira vida livre e civil" (HF, III.V: 168-169). A Senhoria era também provocada a reconhecer que, mesmo com a queda da velha ordem, "a soberba e a ambição dos Grandi não se extinguiram, mas foram arrebatadas por nossos homens do povo que, agora, segundo o costume dos ambiciosos, procuram obter o primeiro posto na república" (HF.III.5:167).

No capítulo seguinte, Maquiavel revela que a Senhoria se mostrou receptiva à demanda contida no discurso. Contudo, as providências para reformar a república incidiram apenas sobre os efeitos do comportamento faccioso, negligenciando totalmente suas causas. Na ausência de alterações significativas no ordenamento institucional, tratou-se apenas de impedir que os membros mais reputados, tanto dos Albizzi como dos Ricci, ocupassem magistraturas por um período determinado. É relevante o juízo de Maquiavel acerca das ações resultantes do discurso moralista dirigido à Senhoria: "Aqueles cidadãos pensaram mais em extinguir as facções do momento do que em fechar os caminhos para as futuras, de tal modo que não conseguiram nem uma coisa nem outra". O recrudescimento da corrupção era uma consequência previsível, uma vez que eles "não extinguiram as razões para o surgimento de novas facções" (HF.III.6:169) ${ }^{14}$. Mas o que poderia significar "extinguir as razões" do facciosismo? 
Embora seja incorreto supor que Maquiavel via na desigualdade a única causa da formação de facções e de estímulo à corrupção, é lícito afirmar que sem que se a leve em consideração, especialmente em sua dimensão material, permanecemos sem uma explicação razoável desses fenômenos. Para se ter uma ideia mais exata dos mecanismos mobilizados pelos "nobres populares" com o fim de cativarem sua clientela e assegurarem o controle do estado, nada é mais instrutivo do que a análise de Maquiavel sobre o triunfo dos Medici. A estratégia adotada pelo florentino para instruir seus leitores jamais é explicitada em seus textos. Mas há um documento histórico de grande significação para o esclarecimento dessa questão. Trata-se de uma carta de Donato Giannotti, um jovem amigo e interlocutor de Maquiavel, a um cidadão de nome Marcantonio Micheli. Giannotti relata que Maquiavel teve muita dificuldade para chegar ao tom certo para descrever adequadamente as coisas relativas aos Medici na História de Florença, mas que, enfim, encontrara uma solução. Segundo o missivista, Maquiavel confidenciou-lhe a estratégia a ser adotada nos seguintes termos:

\footnotetext{
Donato, não posso escrever esta História começando quando Cosimo tomou o governo até a morte de Lorenzo como teria feito se me encontrasse livre de qualquer obrigação. Os fatos serão relatados veridicamente e não omitirei nenhum, e só deixarei de discorrer sobre as causas gerais das coisas. Assim, enunciarei os fatos ocorridos quando Cosimo tomou o governo, mas não direi com que meios e manobras uma pessoa atinja tamanha altura. E quem desejar entender também isso, note muito bem o que farei seus adversários dizerem, porque o que não desejaria dizer eu, como se coisa minha fosse, farei seus adversários dizerem (apud Ridolfi, 2003:228).
}

Esse depoimento sugere o seguinte: primeiro, por razões discutidas no início desta seção, o autor não se encontrava em posição de escrever sem algum tipo de censura ou autocensura; segundo, esse fato o levou a silenciar sobre as "causas gerais" dos acontecimentos; terceiro, o leitor interessado em saber a verdade sobre os meios mobilizados pelos Medici para tornarem-se senhores de Florença devem examinar com cuidado as palavras que o contido escritor põe na boca dos adversários de Cosimo. A meu ver, o exame deste último ponto provê elementos para corroborarmos a hipótese de que, para Maquiavel, sociedades com níveis elevados de desigualdade econômica constituem solo fértil para a corrupção da vida cívica. 
Não eram poucos os membros das famílias abastadas de Florença que alimentavam receios em relação às pretensões de Cosimo de Medici, àquela altura reputado como um dos homens mais ricos do mundo (Hibbert, 1979:24). A casa dos Albizzi, em especial, fazia tenaz oposição a ele. Mas Maquiavel prefere chamar a atenção do leitor para os métodos de Cosimo através das palavras de Niccollò da Uzzano, ele próprio um cidadão riquíssimo e detentor do cargo de gonfaloneiro. Uzzano já havia aparecido nas páginas dos Discursos como ilustração da tese de que atacar de frente um mal que tenha crescido muito numa república pode ter consequências perversas, agravando o mal que se pretendia debelar. Apresentado como "homem de grande perícia nas coisas civis" (D.I.33:104), Uzzano foi prudente o bastante para evitar que Rinaldo degli Albizzi e seus aliados investissem contra Cosimo, tentando levá-lo ao exílio ou à morte. Maquiavel assinala que "as coisas e modos extraordinários de proceder eram sobejamente conhecidos por Niccolò da Uzzano", embora fosse ele "o primeiro a não gostar das vias extraordinárias" (HF.IV.26:263-264). Procurado por um dos exaltados conspiradores contra Cosimo, Uzzano alongou-se em uma lição de realismo político. Sugeriu a Barbadoro que, antes de tomarem qualquer iniciativa, comparassem suas forças com as de Cosimo. Assim deveriam concluir que "nosso partido está desmembrado e o dos adversários está íntegro" (HF.IV.26:264). Mas a questão de fundo era compreender as razões do poder de Cosimo. Como o fundador do principado mediceu conquistou tamanha reputação? Sem esconder sua "suspeita de que Cosimo se torne príncipe desta cidade", Uzzano revela que os métodos que multiplicaram o poder dos Medici incluíam: "pôr seu dinheiro à disposição de todos, não somente dos cidadãos privados, mas também do público, e não só dos florentinos, mas também dos condottieri". Também se dispunha a "ajudar este ou aquele que precisa de magistrados", além de alçar "este ou aquele amigo a postos mais honrosos". O problema é que poucos viam a maldade intrínseca de tais procedimentos, que em vez de despertarem a suspeita do conjunto dos cidadãos, reforçavam em Cosimo a reputação de "piedoso, solícito, liberal e amado por todos" (HF.IV.27:265-266).

Uzzano enfatiza a dificuldade de combater esses meios "aptos a levar voando ao principado", pois condená-los seria como endossar improváveis leis que proibissem ou censurassem "a piedade, a liberalidade e o amor". Tão inútil quanto forçar o exílio de Cosimo seria condená-lo à morte. O orador adverte seu ouvinte de que "se tiverdes em mente fazê-lo condenar à morte, não o conseguiríeis por meio dos magistra- 
dos". E a razão disso é elementar, "porque o dinheiro dele e os vossos ânimos corruptíveis sempre o salvarão" (HF.IV.27:266). O dinheiro dos Medici era o fator decisivo não apenas pela quantia monumental a seu dispor, mas sobretudo pelo uso que dela faziam. Comparando o fundador do regime dos Medici com outros poderosos de Florença, Maquiavel afirma que ele "sobrepujou todos os outros de seu tempo em liberalidade e riqueza", destacando que "não havia na cidade cidadão de algum valor a quem Cosimo não tivesse emprestado grande soma em dinheiro." Ao deparar-se com algum nobre em dificuldade financeira, o generoso banqueiro "dava-lhe ajuda sem que lhe pedissem" (HF.VII.5:429).

E não era apenas fazendo empréstimos generosos aos grandi e distribuindo prebendas privadas que Cosimo trilhava a rota da tirania. Para o benefício da Igreja e o desfrute do religioso povo florentino, ele edificou "conventos", "igrejas" e "mosteiros". Não satisfeito em exercer sua caridade em Florença e em toda a Itália, "construiu em Jerusalém um albergue para peregrinos pobres e enfermos". A tudo isso deve-se acrescentar os palácios que ergueu para sua própria família, um na cidade e mais quatro em localidades vizinhas: "palácios dignos de reis, e não de cidadãos privados." Maquiavel enfatiza o óbvio quando diz que "em tais edificações [Cosimo] despendeu uma imensa quantidade de dinheiro" (HF.VII.5:430). Sua fortuna era tanta, que o permitia ir além de angariar apoios em Florença, sendo-lhe também decisiva nas relações com outras cidades. Foi assim que, "com o crédito de que gozava, privou Nápoles e Veneza de dinheiro", forçando-as a aceitar um tratado de paz que não desejavam (HF.VII.5:431). Definitivamente, o dinheiro era a fonte do poder de Cosimo. O caso dos Medici representa uma infração acintosa à já mencionada prescrição de Maquiavel para a boa ordem republicana, segundo a qual o público deve ser rico e o cidadão, pobre. Tanto os iludidos de boa-fé como os ambiciosos de todos os tipos louvavam a "liberalidade" de Cosimo, enquanto tornavam-se dependentes de suas obras. A nova modalidade de corrupção se espalhava pela cidade. Não é de modo algum absurda a hipótese de um endosso de Maquiavel às duras palavras que concluem o discurso de Niccolò da Uzzano: "todos esses cidadãos, em parte por ignorância, em parte por malícia, estão dispostos a vender esta república; e a fortuna é tão amiga deles que encontraram o comprador" (HF. IV.27:267). 
A prova de que a "tirania soft" (Zuckert, 2017:434) dos Medici assentava-se no modo de uso de sua descomunal riqueza material e financeira veio na época de Piero de Medici, filho e sucessor de Cosimo. Dolosamente aconselhado por Dietisalvi, um antigo servidor de confiança de seu pai, quem, por ambição, passou a desejar-lhe a ruína, Piero tentou cobrar os débitos de todos os devedores da família para fazer frente a graves dificuldades financeiras. Dado que Cosimo, "para conquistar partidários em Florença e aliados fora da cidade", fora sempre "extremamente liberal", o resultado é que "não era pequena nem de pouca importância a soma de dinheiro de que era credor". A tentativa de Piero quase o levou a ruína, pois "tão logo fez com que pedissem o dinheiro de volta, os cidadãos se ressentiram, por acharem que ele estava querendo tirar o que era deles, e não pedindo o que era seu; e, sem nenhum respeito, falavam mal dele, caluniando-o de ingrato e ganancioso" (HF.VII.11:441).

A explicitação dos meios que pavimentaram o caminho dos Medici ao poder corrobora a hipótese de que a corrupção das repúblicas tem na desigualdade econômica uma de suas causas principais. Se o leitor fizer abstração da imensa riqueza acumulada pela célebre família de banqueiros, os mecanismos pelos quais eles tornaram-se "príncipes" da cidade permanecem fora do campo de visão. As estratégias dos Medici ilustram, à perfeição, os danos que a necessidade de conquista de reputação pode trazer para a preservação da virtude cívica e da liberdade. Maquiavel reconhece que uma república bem ordenada não pode prescindir de cidadãos de elevada reputação. Ele já havia tratado desse tema nos Discursos, onde esclarece que há dois modos de conquista de reputação nas repúblicas: o público e o privado. O primeiro leva ao engrandecimento da cidade, o segundo, à corrupção e à tirania.

O título do capítulo 28 do livro terceiro pode ser compreendido como um endosso das suspeitas de Uzzano sobre as intenções de Cosimo. Nele se lê que "é preciso estar atento às obras dos cidadãos, pois muitas vezes, encoberto sob obra de boa-fé, está um princípio de tirania" (D.III.28:406). Mas, nesse capítulo, Maquiavel estava tratando da virtuosa Roma, e não da corrupta Florença. O personagem que ilustra a tese não é o bem-sucedido Cosimo, mas um cidadão romano de nome Espúrio Mélio, um homem "bem rico para os moldes daqueles tempos." Vendo numa onda de fome que assolava a plebe romana uma oportunidade para aumentar sua reputação, Espúrio Mélio "resolveu fazer uma provisão particular de frumento e, às suas expensas, ali- 
mentar a plebe". A doação, que de fato aumentou seu prestígio junto à plebe, também chamou a atenção do Senado, alerta ao "inconveniente que aquela liberalidade podia originar". Em notável contraste com o procedimento dos magistrados florentinos em relação a Cosimo, o Senado da república romana detectou cedo o potencial corruptor das obras de Espúrio Mélio e "condenou-o à morte" (D.III.28,406).

O caso de Espúrio Mélio serve como demonstração exemplar tanto dos perigos do "modo privado" de conquista de reputação, como do tratamento que a república romana reservava a esses perigos. Nas "repúblicas bem-ordenadas", o caminho deve estar aberto à conquista de reputação pelos modos públicos, "oferecendo prêmios" aos cidadãos que vivem "aconselhando bem e agindo melhor em prol do bem público". Por outro lado, essas repúblicas devem obstar por todos os meios, inclusive os mais severos, a conquista de reputação por modos privados, pois a reputação desse modo conquistada é "perigosíssima e de todo nociva" (D.III.28:406-407). É impossível não lembrar do juízo de Uzzano sobre os métodos de Cosimo quando Maquiavel afirma que as deletérias "vias privadas consistem em fazer benefícios a este e àquele, emprestar-lhe dinheiro [...], defendê-lo dos magistrados, prestando favores privados semelhantes, que fazem partidários e estimulam os que são assim favorecidos a corromper o público e enfraquecer as leis" (D.III.28:407).

Maquiavel volta ao tema no capítulo inicial do livro sétimo da História de Florença, reafirmando que "há dois modos de conquistar reputação nas cidades: por meios públicos ou por meios privados" (HF. 7.1:422). No essencial, o enquadramento do tema se repete, mas o autor acrescenta esclarecimentos. Além de ampliar o rol de exemplos dos meios públicos ${ }^{15}$, ele enfatiza o nexo entre o uso dos meios privados e a formação de facções. A caracterização dos meios privados é basicamente a mesma que aparece nos Discursos. Assim, o líder corruptor é alguém sempre pronto a beneficiar este ou aquele cidadão, "defendendo-o perante os magistrados, ajudando-o com dinheiro, alçando-o a cargos não merecidos". Mas agora acrescenta-se outra estratégia: "agradando a plebe com jogos e doações públicas" (HF. 7.1:422). Do uso recorrente desses meios "nascem as facções e os partidários", que fomentam as divisões "prejudiciais à república". E poucas repúblicas foram por tais razões tão prejudicadas quanto a de Florença, pois suas inimizades "sempre foram acompanhadas de facções e, por isso, sempre danosas" (HF. VII.1:423). 


\section{CONSIDERAÇÕES FINAIS}

Este artigo procurou elucidar o sentido da relação entre desigualdade e corrupção no republicanismo de Maquiavel. Para o florentino, a corrupção decorre de uma desigualdade que, embora multidimensional, não pode prescindir da dimensão socioeconômica para sua adequada conceituação. Confrontado com a tarefa de explicar as causas da corrupção da república romana, Maquiavel dirigiu sua atenção aos conflitos desencadeados pelas reformas redistributivistas dos irmãos Graco. Quando o objeto das demandas da plebe se desloca da esfera do reconhecimento para a esfera da redistribuição, os conflitos entre os grandes e a plebe deixam de trazer os costumeiros benefícios e passam a gerar facciosismo, violência e desordem. Em Roma, o fato social subjacente à degeneração dos conflitos foi a extrema concentração de terras nas mãos de um patriciado obstinado na defesa de seus interesses materiais. No caso de Florença, especialmente depois da exclusão dos magnatas, o facciosismo e a corrupção foram impulsionados pela imensa riqueza acumulada por famílias dedicadas ao comércio e às finanças. Mesmo constrangido por um contexto pessoal que o impedia de falar abertamente sobre as causas da corrupção em sua própria cidade e em seu próprio tempo, Maquiavel dispensa o recurso de falar nas entrelinhas, preferindo elaborar uma explicação do fenômeno da corrupção à moda de uma ciência política interpretativa, na qual a lógica do processo se revela na descrição das ações e dos discursos dos agentes em conflito. É isto o que ele faz na análise do processo de corrupção protagonizado pelos Medici. Criando com seus próprios termos as falas de personagens antimediceus, o teórico florentino deixa claro que, por meio de práticas de benemerência e patronagem, a poderosa família mobilizava sua imensa riqueza fungível para conquistar partidários e fazer prevalecer suas facções no governo da república.

Argumentei que a elisão das condições materiais da desigualdade é uma limitação a ser superada em algumas das mais influentes interpretações neorrepublicanas de Maquiavel. Sem dar a devida atenção ao postulado maquiaveliano de que o crescimento desmesurado da riqueza privada e, consequentemente, da desigualdade socioeconômica são fatores causais dos fenômenos relativos à corrupção das repúblicas, historiadores e teóricos neorrepublicanos fazem demasiadas concessões aos aspectos mais aristocráticos - e mesmo oligárquicos - da 
tradição do republicanismo clássico. Isto os inibe no cumprimento de seu próprio objetivo de atualizar da tradição republicana de um modo plenamente compatível com o imperativo democrático de nossa época.

Creio ser correta a tese dos neorrepublicanos de que o igualitarismo de Maquiavel se expressa em um projeto de estabilização da "constituição mista", um acervo institucional de distribuição de poder político ancorado na crença republicana clássica da preeminência do império da lei sobre o império dos homens. Não há razão para refutar essa ênfase jurídica que os neorrepublicanos dão ao republicanismo democrático de Maquiavel (Silva, 2018). Entretanto, parece-me necessário complementar essa interpretação com um enfoque mais sociológico, destinado a lançar luz sobre o fato de que entre os diversos impedimentos para a fundação de uma república e entre as diversas causas de sua corrupção, encontra-se a ampliação da distância que separa os ricos dos pobres, dicotomia expressiva da dimensão material do antagonismo entre as categorias mais compreensivas dos "grandes" e do "povo". A contribuição de Maquiavel para a articulação de um conceito contemporâneo de "democracia republicana" (Silva, 2015b) reside em conciliar a exigência da igualdade jurídico-política com a crítica ao aprofundamento da desigualdade socioeconômica.

Vale encerrar com a sugestão de que as reflexões de Maquiavel sobre a relação entre desigualdade e corrupção tem o potencial de promover um refinamento conceitual na teoria neorrepublicana da liberdade. Autores como Quentin Skinner e Philip Pettit têm insistido, com propriedade, que a tradição republicana que eles procuram reviver tem como valor central uma visão da liberdade como ausência de dependência, sendo a dependência o núcleo definicional do conceito de dominação. Daí a fórmula da "liberdade como não dominação"16. Mas algo fica de fora dessa conceituação, uma vez que a dominação não esgota todas as manifestações da dependência. Como observa Pettit, a dominação consiste na submissão de um agente ao poder arbitrário de outro. Ela pressupõe recursos coercitivos que o agente dominante pode mobilizar contra o agente dominado para assegurar submissão e obediência. Dentre tais recursos, destaca-se a desigualdade de estatuto jurídico. Não é por acaso que o paradigma da escravidão é tão caro aos neorrepublicanos. De qualquer modo, a dominação só é possível devido a ameaça credível de uma interferência do dominante piorar imediata e efetivamente a situação do dominado, causando-lhe algum tipo de dano (Pettit, 1997:52). 
Todavia, nem toda relação de dependência identifica-se à dominação nos termos acima definidos (Sparling, 2013). Alguém pode se tornar dependente não para evitar um mal, mas para alcançar um bem a si próprio; não para escapar à coerção, mas para obter privilégios e vantagens. Menos explícita e assertiva do que a dependência associada à dominação, essa dependência associada à corrupção é, por outro lado, mais insidiosa e, no mínimo, igualmente lesiva à liberdade republicana. Não é necessariamente a desigualdade perante a lei - ou a desigualdade de status - que se encontra na base dessa forma de dependência, porém significativos níveis de desigualdade material entre os cidadãos. A dependência corruptora é uma desordem social caracterizada pela situação inversa à desejada por Rousseau (1999:63), ou seja, ela ocorre sempre que há cidadãos tão pobres que tenham de se vender e outros tão ricos que os possam comprar.

(Recebido para publicação em 27 de março de 2019)

(Reapresentado em 30 de junho de 2019)

(Aprovado para publicação em 29 de julho de 2019)

\section{NOTAS}

1. As citações das obras de Maquiavel serão referenciadas pelas iniciais dos títulos, seguidas do número do livro e/ou do capítulo e página de cada obra. Identificaremos as obras pelas iniciais dos títulos em edições brasileiras: D para Discursos sobre a primeira década de Tito Lívio, HF para História de Florença, P para O Príncipe e DFGF para Discurso sobre as formas de governo de Florença. As edições usadas encontram-se na bibliografia ao final do artigo. As traduções das citações dos textos consultados em língua estrangeira são de minha autoria.

2. No final do capítulo, Maquiavel repete a fórmula. E ele volta a ela em breve texto, escrito entre 1520 e 1521, sob encomenda do papa Leão X, eminente membro da família Medici, a quem Maquiavel oferece uma lição nos seguintes termos: "Vossa Santidade deve, pois, compreender o seguinte: que, em todas as cidades nas quais é grande a igualdade entre os cidadãos, não se pode ordenar um principado senão com máxima dificuldade, e que, naquelas cidades nas quais é grande a desigualdade entre os cidadãos, não se pode ordenar uma república" (DFGF:66).

3. Para ser preciso, destaco que Maquiavel não usa o termo "causa" para se referir à relação entre desigualdade e corrupção. No entanto, creio ser justificável meu uso, tendo em vista uma das possíveis conotações da locução italiana "nasce da", empregada pelo autor na frase que aparece em D.I.17 ("Perché tale corruzione e poca attitudine alla vita libera, nasce da una inequalità che é in quella città"). Além da conotação de causação, mais afim ao vocabulário científico-naturalista, a referida locução pode conotar sentidos de gênese, origem e proveniência, mais afins ao vocabulário historicista.

4. Em seu exame do tema do conflito em História de Florença, Gisela Bock, uma das organizadoras da difundida coletânea Machiavelli and republicanism (1990), chega a uma conclusão 
que, em certos aspectos, aproxima-se da leitura de Pocock. Para a historiadora alemã, "a 'igualdade' de Maquiavel não é econômica ou social, mas legal e política, significando igualdade perante a lei e igualdade de acesso a cargos públicos" (Bock, 1990:189).

5. A política dos Gracos encontra registros nas obras de clássicos da historiografia de Roma, especialmente em Tito Lívio, Apiano e Salústio, bem como entre os gregos, a exemplo de Plutarco e Dionísio de Halicarnasso. Conforme observa Eric Nelson (2004), entre os pensadores da antiguidade, o tom de aprovação dos autores gregos em relação às reformas dos Gracos contrastava fortemente à avaliação enfaticamente reprobatória dos autores romanos, com a solitária exceção de Salústio. Contudo, como destaca Nelson, "mesmo a poderosa voz de Salústio seria mais do que afogada pela retórica expansiva do maior opositor das leis agrárias: Marcus Tullius Cícero." (p. 57).

6. A prescrição para o enriquecimento público e o empobrecimento dos cidadãos não deve ser entendida em termos de níveis absolutos de riqueza e pobreza. A prescrição tem mais a ver com a limitação de níveis extremos de desigualdades materiais entre cidadãos ou entre estes e a cidade (McCormick, 2018), bem como com o cultivo de determinadas atitudes que afirmam a dignidade da pobreza (Rose, 2016). Ver também Castillo Vegas (2013).

7. A crítica ao imprudente erro de "timing" dos Gracos parece derivar diretamente da lição oferecida por Maquiavel em capítulo anterior ao da lei agrária. Como evidencia o próprio enunciado que dá título ao capítulo 33 do livro primeiro, “Quando um inconveniente tiver crescido num estado ou contra um estado, será mais salutar temporizá-lo do que atacá-lo de frente" (D.I.33:102).

8. A natureza retórica da teoria política de Maquiavel tem sido objeto de cuidadosos estudos. Por exemplo: Kahn (1994), Viroli (1998) e Adverse (2009).

9. Estudos recentes têm renovado o interesse no naturalismo subjacente à filosofia de Maquiavel. Em uma de suas mais importantes vertentes, o naturalismo chega ao cenário intelectual da Renascença por meio da influência do epicurismo, sobretudo pela via filósofo latino Lucrécio, cujo poema De Rerum Natura Maquiavel copiou integralmente de próprio punho em meados dos anos 1490 (Rahe, 2007; Brown, 2015; Del Lucchese, 2015; Costa, 2019). O atomismo de Lucrécio, com sua concepção de que todos os eventos são resultantes da necessidade e do acaso, encontra eco em inúmeras ocasiões em que Maquiavel destaca a natureza imprevisível e, a partir de certo ponto, incontrolável da fortuna. Também expressiva do naturalismo maquiaveliano é a cosmologia que concebe as "coisas do mundo" como eventos determinados parcialmente pelo movimento dos corpos celestes. Conforme bem observou Anthony Parel, para o pensador florentino "o movimento da história não é um resultado do movimento humano completamente autônomo (...) Tudo o que acontece na história, acontece de acordo com as leis do movimento cósmico. Rigorosamente falando, a história é um produto da articulação entre movimentos cósmicos e humanos, em que um joga o papel superior e o outro um papel subordinado" (Parel, 1992: 321-322). Agradeço ao parecerista de Dados pela sugestão que suscitou esta nota e o parágrafo em que ela se insere.

10. Como se sabe, é o próprio Maquiavel quem lança essa dúvida. Por vezes ele afirma que Florença sempre oscilou entre "república e principado" (DFGF:59); outras vezes, ainda pior, entre "servidão e licença" (HF.4.1:221). Sobre as razões desse sentimento ambíguo 
de Maquiavel por Florença, um misto de afeição patriótica e desilusão, ver: Jurdjevic (2014).

11. Ainda na prisão, Maquiavel soube da execução de dois conspiradores aprisionados antes dele. Porém, quer pela precariedade do indício de sua participação na conspiração, que se limitava à inscrição de seu nome numa lista encontrada com um dos conspiradores executados, quer pela provável interferência de Giuliano, seu único amigo entre os Medici, Maquiavel foi libertado nos indultos em comemoração à eleição de Leão X, o primeiro papa da rica família florentina.

12. É bem conhecida uma das principais diferenças indicadas por Maquiavel entre Roma e Florença. Enquanto em Roma as disputas terminavam em "debates", em Florença elas terminavam em "combates". Cf. HF. III.1.

13. A atribuição de discursos a personagens reais ou fictícios, nomeados ou anônimos, é um recurso sistematicamente explorado por Maquiavel na História de Florença. Esse recurso é útil a diversos propósitos do autor. Além de lhe permitir proceder à maneira do cientista social interpretativista, que procura reconstituir as ações baseando-se no ponto de vista dos próprios agentes envolvidos, os discursos citados servem como veículo para que o autor expresse determinados enunciados e chegue a determinadas conclusões que, reconhecidos como seus, poderiam comprometer tanto sua estratégia retórica de persuasão, como sua própria segurança. Sobre a importância dos discursos fictícios em Maquiavel, ver Winter (2012:751). A polifonia dos discursos, além de ter uma função teórica, favorece a dimensão normativa do perspectivismo maquiaveliano. Segundo Litvin (2019:6), em Maquiavel, “o perspectivismo não é simplesmente uma ferramenta literária na teorização de atores e situações, mas principalmente um modo de intervenção política destinada a conduzir e desafiar dada dinâmica entre o teórico, o ator e a audiência".

14. O conflito entre a facção "popular" e a facção plebeia atingiu o zênite em 1378, na chamada revolta dos Ciompi, um movimento dos trabalhadores mais pobres da cadeia produtiva da economia florentina e destituídos de representação própria no sistema de guildas. A revolta, caracterizada pela explosão da violência plebeia contra os "nobres populares", põe em evidência a natureza a um só tempo política e econômica das disputas. No capítulo XVI do livro terceiro, naquele que é provavelmente o mais célebre discurso inventado por Maquiavel, um ciompo anônimo irrompe à cena e fala longamente a seus pares com o fim de os persuadir a seguir a marcha violenta da revolta já iniciada. O discurso tem seu foco no tema da desigualdade, especialmente a desigualdade econômica. Segundo Vivanti (2016:148), "as palavras do ciompo denunciam a força da economia como motor dos acontecimentos que conduziram à insurreição". Também nesse discurso, proliferam ideias e expressões recorrentes na obra de Maquiavel. Quando o ciompo afirma que "todos aqueles que conseguem grandes riquezas e grande poder os conseguiram com a fraude ou com a força", é impossível não lembrarmos do capítulo 13 do livro segundo dos Discursos, que já no título indica a lição de "que se passa da pequena para a grande fortuna por meio da força e da fraude" (D.II.13:223). Em expressão que sintetiza o igualitarismo socioeconômico e radical do movimento, o orador, comparando os pobres e malvestidos cardadores aos nobres, conclui que "somente a pobreza e a riqueza nos desigualam" (HF. III.13:185). Não há espaço para examinarmos, aqui, as implicações do episódio dos Ciompi na visão de Maquiavel sobre a igualdade. Pela importância histórica do evento e pela dramaticidade da narrativa de Maquiavel, a revolta dos Ciompi tem sido objeto de 
Ricardo Silva

inúmeros estudos recentes. Uma lista breve inclui autores como Pedullà (2005), Winter (2012), Leibovici (2002), Lukes (2009) e McCormick (2017).

15. "Por meios públicos a reputação é conquistada por quem vence uma batalha, ocupa uma cidade, cumpre uma missão com presteza e prudência, dá conselhos sábios e vantajosos à república" (HF. 7.1:422).

16. A fórmula, como se sabe, foi cunhada por Pettit. Mas o filósofo irlandês revela a importância das contribuições historiográficas de Skinner como ponto de partida de sua elaboração conceitual (Pettit, 1997: IX, 7, 27). Skinner, por sua vez, a partir da formulação de Pettit, modifica os termos de seus primeiros estudos sobre o tema. Inicialmente, ele entendia a liberdade republicana como uma modalidade de liberdade negativa quase idêntica à concepção hobbesiana e liberal desse conceito, caracterizada pela ausência de coerção (Skinner, 1984: 217). A única e importante distinção era aquela relativa ao valor instrumental da participação política no ideal republicano, valor dispensável (ou até prejudicial) no liberalismo. Já em meados da década de 1990, Skinner passa a postular a ausência de dependência (independência), ao lado da ausência de coerção, como um dos traços distintivos da liberdade republicana (Skinner, 1997). Insatisfeito com essa dualidade na formulação de Skinner, Pettit sugere a Skinner uma "simplificação" do ideal republicano de liberdade, de modo que ele dispensasse o critério de ausência de coerção e mantivesse apenas o critério de ausência de dependência no núcleo da definição do conceito de liberdade republicana (Pettit, 2002). E isso devido à possibilidade de identificação entre dependência e dominação. Como sustenta Pettit, "o postulado de Skinner de que os republicanos se preocupam com a dependência é claramente convergente com meu próprio postulado de que eles se preocupam com a dominação. Onde Skinner fala de dependência da boa vontade de outrem, eu falo em ser dominado. Ser dominado envolve ocupar a posição na qual um terceiro possa interferir em bases arbitrárias em sua vida" (Pettit, 2002:341). A julgar pelas incursões mais recentes de Skinner no tema da liberdade republicana (Skinner, 2008 e Skinner, 2010), creio ser possível afirmar que o historiador tenha tomado a sério e aceitado sem restrições a sugestão de Pettit. Assim, nas formulações mais recentes tanto de Skinner como de Pettit, "poder arbitrário", "dependência" e "dominação" são diferentes termos para designar o mesmo fenômeno. A outro parecerista de DADOS sou grato pela questão que suscitou esta nota. 


\section{REFERÊNCIAS}

ADVERSE, Helton. (2009), Maquiavel: política e retórica. Belo Horizonte: Editora da UFMG.

BIGNOTTO, Newton. (1991), Maquiavel Republicano. São Paulo: Loyola.

BLACK, Robert. (2013), Machiavelli. London: Routledge.

BOCK, Gisela. (1990), “Civil Discord in Machiavelli Istorie Fiorentine”. In: G. Bock; Q. Skinner; M. Viroli (eds.), Machiavelli and Republicanism. Cambridge: Cambridge University Press, pp. 181-201.

BROWN, Alison. (2015), "Lucretian naturalism and the evolution of Machiavelli's ethics". In: Del Lucchese et al. (eds.), Radical Machiavelli. Boston: Brill, pp. 105-127.

CADONI, Giorgio. (2017), “Machiavelli: corruzione, 'inequalità', conflitti”. La Cultura, v. 40, n. 2, pp. 207-236.

CASTILLO VEGAS, Jesús. (2013), “Ciudad rica y ciudadanos pobres. La consideración de la riqueza em el republicanismo florentino". Ingenium - Revista de Historia del Pensamiento Moderno, n. 7, pp. 71-91.

COSTA, Jean Castro da. (2019), “Maquiavel, pensador trágico. Lua Nova”, n. 107, pp. 127-168.

DEL LUCCHESE, Filippo Del. (2015), The political philosophy of Niccolò Machiavelli. Edinburgh: Edinburgh University Press.

FONTANA, Benedetto. (2017), “Machiavelli and the Gracchi: republican liberty and class conflict". In: N. Urbinati; D. Johnston; C.Vergara (eds.), Machaivelli on liberty and conflict. Chicago, Chicago University Press, pp. 235-256.

HIBBERT, Christopher. (1979), The rise and fall of the house of Medici. Westminster: Penguin.

JURDJEVIC, Mark. (2014), A great and wreatched city: promise and failure in Machiavelli's Florentine Political Thought. Cambridge: Harvard University Press.

KAHN, Victoria. (1994), Machiavellian Rhetoric: from Conter-Reformation to Milton. Princeton/ NJ: Princeton University Press.

KOCIS, Robert. (1998), Machiavelli redeemed: retrieving his humanist perspectives on equality, power, and glory. London: Associated University Press.

LABORDE, Cecile; MAYNOR, John (eds). (2008), Republicanism and political theory. Oxford: Blackwell.

LEIBOVICI, Martine. (2002), "From fight to debate: Machiavelli and the Revolt of the Ciompi". Philosophy and Social Criticism, v. 28, n. 6, pp. 647-660.

LITVIN, Boris. (2019), "Mapping the rule and subversion: perspective and democratic turn in Machiavelli Scholarship". European Journal of Political Theory, v. 18, n. 1, pp. 3-25.

LUKES, Timothy. (2009), “Descending to the particulars: the Palazzo, the Piazza, and Machiavelli's republican modes and orders. The Journal of Politics, v. 71, n. 2, pp. 520-532.

MAHER, Amanda. (2016), “What Skinner Misses about Machiavelli's freedom: inequality, corruption, and the institutional origins of civic virtue". The Journal of Politics, v. 78, n. 4, pp. 1003-1015. 
Ricardo Silva

MAHER, Amanda. (2020), “The power of 'wealth, nobility, and men': Inequality and corruption in Machiavelli's Florentine Histories". European Journal of Political Theory, v. 19, n. 4. pp. 512-531.

MAQUIAVEL, Nicolau. (2007a), Discursos sobre a Primeira Década de Tito Lívio. São Paulo: Martins Fontes.

. (2007b), História de Florença. São Paulo: Martins Fontes.

. (2010), "Discurso sobre as Formas de Governo de Florença". In: H. Adverse (org.). Maquiavel: diálogo sobre a nossa língua e discurso sobre as formas de governo de Florença. Trad. Gabriel Pancera. Belo Horizonte: Editora da UFMG.

. (2017), O Princípe. Trad. Diogo Pires Aurélio. São Paulo: Editora 34.

MAYNOR, John. (2003), Republicanism in the modern world. Cambridge (UK): Polity Press.

MCCORMICK, John P. (2003), “Machiavelli against Republicanism on Cambridge School's “Guicciardinan Moments'”. Political Theory, v. 31, n. 5, pp. 615-643.

. (2006), "Tempering the grandi's appetite to oppress: the dedication and intention of Machiavelli's Discourses". In: V. Kahan; N. Saccamanto; D. Coli (eds.), Politics and Passions, 1500-1850. Princeton: Princeton University Press, pp. 7-29.

. (2009), "Machiavelli and the Gracchi: prudence, violence and redistribution". Global Crime, v. 10, n. 4 .

. (2018), "Keep the public rich, but the citizens poor: economic and political corruption in the Discourses". In: J. Mccormick. Reading Machiavelli: scandalous books, suspect engagements, and the virtue of populist politics. Princeton: Princeton University Press.

. (2017), Machiavelli, popular resistence and the curious case of Ciompi Revolt. Trabalho apresentado na conferência Theorising Resistance. Reading University, 9-10 de junho.

MCKENZIE, Lionel. (1982), "Rousseau's debate with Machiavelli in the Social Contract". Journal of the History of Ideas, v. 43, n. 2, pp. 209-228.

NADON, Christian. (1996), "Aristotle and the republican paradigm: a reconsideration of Pocock's Machiavellian Moment". The Review of Politics, v. 58, n. 4, pp. 677-698.

NAJEMY, John. (1982), "Machiavelli and the Medici: the lessons of florentine history". Renaissance Quarterly, v. 53, n. 4, pp. 551-576.

. (2006), A history of Florence: 1200-1575. Oxford: Blackwell.

NELSON, Eric. (2004), The Roman Agrarian Laws and Machiavelli's Modi Privati. In: The Greek Tradition in Republican Thought. Cambridge: University Press, pp. 49-86.

OSTRENSKY, Eunice. (2019), “Maquiavel: a ambição e o dilema das leis agrárias”. Lua Nova, n. 107 , pp. 55-90.

PAREL, Anthony. (1992), "The question of Machiavelli's modernity". Review of Politics, v. 53, n. 2, pp. 320-339.

PEDULLÀ, Gabriele. (2003), “Il divieto di Platone: Machiavelli e il discorso dell'anonimo plebeo". In: J-J, Marchand; J-C Zancarini (eds.), Storiografia Repubblicana Fiorentina (14941570). Firenzi: Cesati, pp. 209-266. 
Desigualdade e Corrupção no Republicanismo de Maquiavel

(2018), Machiavelli in Tumult. Cambridge: Cambridge University Press.

PETTIT, Philip. (1997), Republicanism: a theory of freedom and government. Oxford: Oxford University Press.

(2002), "Keeping republican freedom simple: on a difference with Quentin Skinner". Political Theory, v. 30, n. 3, pp. 339-356.

POCOCK, John. (2003), The Machiavellian moment: Florentine Political Thought and the Antlantic Republican Traditition. $2^{\mathrm{a}}$ ed. Princeton: Princeton University Press.

RAHE, Paul. (2007), "In the shadow of Lucretius: the epicurean foundations of Machiavelli's Political Thought". History of Political Thought, v. 28, n. 1, pp. 30-55.

RAIMONDI, Fabio. (2018), Constituting Freedom: Machiavelli and Florence. Oxford: Oxford University Press.

RIDOLFI, Roberto. (2003), Biografia de Nicolau Maquiavel. São Paulo: Musa.

RODGERS, Daniel. (1992), "Republicanism: the career of a concept". The Journal of American History, v. 79, n. 1, pp.11-38.

ROSE, Julie. (2016), "Keep the citzens poor: Machiavelli's prescription for republican poverty". Political Studies, v. 64, n. 3, pp. 734-747.

ROSELAAR, Saskia. (2010), Public land in the roman republic: a social and economic history of the ager publicus in Italy, 396-89 B.C. Oxford: Oxford University Press.

ROUSSEAU, Jean-Jacques. (1999), O contrato social. São Paulo: Martins Fontes.

SILVA, Ricardo. (2010), "Maquiavel e o conceito de liberdade em três vertentes do novo republicanismo". Revista Brasileira de Ciências Sociais, v. 25, n. 72, p. 37-58.

. (2013), "Da honra ao patrimônio: conflito social e instituições políticas nos Discorsi de Maquiavel". Revista Brasileira de Ciência Política, n. 12, pp. 43-66.

. (2015a), "Visões da liberdade: republicanismo e liberalismo no debate teórico contemporâneo". Lua Nova, n. 94, pp. 181-215.

. (2015b), "Non-domination and political institutions: the contested concept of republican democracy". Brazilian Political Science Review, v. 9, n. 1, pp. 3-38.

. (2018), "A república democrática de Maquiavel: uma crítica à interpretação anti-institucionalista". Revista Brasileira de Ciências Sociais, v. 33, n. 8, pp. 1-21.

SKINNER, Quentin. (1984), “The idea of negative liberty: philosophical and historical perspectives". In: Q. Skinner; R. Rorty; J. B. Schnegwind (eds.), Philosophy in history. Cambridge: Cambridge University Press, pp. 194-223.

(1990), "The republican ideal of political liberty". In: Q. Skinner; M. Viroli; G. Bock (eds.), Machiavelli and Republicanism. Cambridge: Cambridge University Press, pp. 293-309.

. (1996), As fundações do pensamento político moderno. Tradução de Renato Janine Ribeiro e Laura Teixeira Motta. São Paulo, Companhia das Letras.

. (1997), Liberty before Liberalism. Cambridge: Cambridge University Press. 
Ricardo Silva

. (2002), Visions of politics, vol II: renaissance virtues. Cambridge: Cambridge University Press.

(2008), "Freedom as the absence of arbitrary power". In: C. Laborde; J. Maynor (eds.), Republicanism and Political Theory. London: Blackwell, pp. 83-101.

. (2010), Hobbes e a liberdade republicana. Tradução de Modesto Florenzano. São Paulo: Unesp.

SPARLING, Robert. (2013), "Political corruption and the concept of dependence in republican thought". Political Theory, v. 41, n. 4, pp. 618-647.

SPARLING, Robert. (2017), "The concept of corruption in J.G.A. Pocock's The Machiavellian Moment". History of European Ideas, v. 43, n. 2, pp. 156-170.

SULLIVAN, Vickie. (1992), “Machiavelli's Momentary 'Machiavellian Moment': A Reconsideration of Pocock's Treatment of the Discourses". Political Theory, v. 20, n. 2, pp. 309-318.

VATTER, Miguel. (2000), Between form and event: Machiavelli's theory of political freedom. Dordrechet: Kluwer.

VIROLI, Maurizio. (1998), Machiavelli. Oxford: Oxford University Press.

VIVANTI, Corrado. (2016), Nicolau Maquiavel: Nos Tempos da Política. São Paulo: Martins Fontes.

WINTER, Yves. (2012), "Plebeian politics: machiavelli and the ciompi uprising". Political Theory, v. 40, n. 6, pp. 736-766.

ZUCKERT, Catherine. (2017), Machiavelli's Politics. Chicago: Chicago University Press. 
RESUMO

Desigualdade e Corrupção no Republicanismo de Maquiavel

O artigo persegue dois objetivos inter-relacionados: 1) contribuir para a interpretação dos enunciados de Maquiavel sobre o papel da desigualdade na corrupção das repúblicas; 2) mostrar que os resultados desse esforço interpretativo contêm lições potencialmente úteis para o redirecionamento e a progressão do programa de pesquisas do republicanismo contemporâneo. Parte-se da hipótese de que os principais expoentes do neorrepublicanismo, em suas leituras de Maquiavel, tendem a subestimar a importância da dimensão socioeconômica da igualdade que embasa a boa ordem republicana. A consequência dessa elisão da dimensão material da igualdade é uma conceituação limitada do tipo de desigualdade que, segundo o pensador florentino, fomenta a corrupção das repúblicas. O argumento desenvolve-se por meio de reconstrução e análise da visão de Maquiavel sobre o papel da desigualdade material na corrupção da república romana, exposta nos Discorsi, e de sua cidade natal, registrada em História de Florença.

Palavras-chave: Maquiavel; neorrepublicanismo; desigualdade socioeconômica; corrupção

\section{ABSTRACT \\ Inequality and Corruption in Machiavelli's Republicanism}

This article focuses on two interrelated goals: 1) to contribute to the interpretation of Machiavelli's statements on the role of inequality in the corruption of republics; 2) to show that the results of this interpretive effort present potentially useful lessons for redirecting and advancing the research program of contemporary republicanism. We start from the hypothesis that the main exponents of neorepublicanism, in their readings of Machiavelli, tend to underestimate the importance of the socioeconomic dimension of equality that underlies the good republican order. The consequence of the elision of the material dimension of equality is a limited conceptualization of the type of inequality that, according to the Florentine thinker, fosters the corruption of republics. The argument is developed through reconstruction and analysis of Machiavelli's view on the role of material inequality in the corruption of the Roman republic, exposed in the Discorsi, and regarding his hometown, recorded in History of Florence.

Keywords: Machiavelli; neorepublicanism; socioeconomic inequality; corruption 


\section{RÉSUMÉ \\ Inégalité et Corruption dans le Républicanisme de Machiavel}

L'article poursuit deux objectifs interdépendants: 1) contribuer à l'interprétation des déclarations de Machiavel sur le rôle des inégalités dans la corruption des républiques; 2) montrer que les résultats de cet effort d'interprétation contiennent des leçons potentiellement utiles pour réorienter et faire avancer le programme de recherche du républicanisme contemporain. Elle part de l'hypothèse que les principaux représentants du néo-républicanisme, dans leurs lectures de Machiavel, tendent à sous-estimer l'importance de la dimension socio-économique de l'égalité qui sous-tend le bon ordre républicain. La conséquence de cette élision de la dimension matérielle de l'égalité est une conceptualisation limitée du type d'inégalité qui, selon le penseur florentin, favorise la corruption des républiques. L'argument est développé à travers la reconstruction et l'analyse de la vision de Machiavel sur le rôle de l'inégalité matérielle dans la corruption de la république romaine, exposée dans les Discorsi, et de sa ville natale, enregistrée dans l'Histoire de Florence.

Mots-clés: Machiavel; néo-publicisme; inégalité socio-économique; corruption

\section{RESUMEN}

Desigualdad y Corrupción en el Republicanismo de Maquiavelo

El artículo persigue dos objetivos interrelacionados: 1) contribuir para la interpretación de los enunciados de Maquiavelo sobre el papel de la desigualdad en la corrupción de las repúblicas; 2) mostrar que los resultados de ese esfuerzo interpretativo contienen lecciones potencialmente útiles para la redirección y el progreso del programa de investigaciones del republicanismo contemporáneo. Se parte de la hipótesis de que los principales exponentes del neo republicanismo, en sus lecturas de Maquiavelo, tienden a subestimar a importancia de la dimensión socioeconómica de la igualdad que es la base del buen orden republicano. La consecuencia de esa elisión de la dimensión material de la igualdad es una conceptuación limitada del tipo de desigualdad que, según el pensador florentino, fomenta la corrupción de las repúblicas. El argumento se desarrolla por medio de la reconstrucción y análisis de la visión de Maquiavelo sobre el papel de la desigualdad material en la corrupción de la república romana, expuesta en los Discorsi, y de su ciudad natal, registrada en Historia de Florencia.

Palabras clave: Maquiavelo; neo republicanismo; desigualdad socioeconómica; corrupción 